\title{
RNA Metabolism during Morphogenesis in Histoplasma capsulatum
}

\author{
By SZE-SHUEN C. CHEUNG, G. S. KOBAYASHI, \\ D. SCHLESSINGER AND G. MEDOFF \\ Divisions of Infectious Disease and Dermatology, Department of Internal Medicine \\ and Department of Microbiology, Washington University School \\ of Medicine, St Louis, Missouri 631 10, U.S.A.
}

(Received 24 September 1973; revised 4 December 1973)

\section{SUMMARY}

During the transition from the mycelial to the yeast form of the dimorphic fungus Histoplasma capsulatum, RNA synthesis decreased to $26.7 \%$ of the normal level for at least $4 \mathrm{~h}$. There was a decrease in total RNA on the first day of mycelial $\rightarrow$ yeast transition. Starting on the second day, RNA synthesis in the mycelial $\rightarrow$ yeast transition phase resumed and this event was paralleled by the emergence of bud-like constrictions on hyphal tips.

\section{INTRODUCTION}

At $25^{\circ} \mathrm{C}$ the dimorphic fungus Histoplasma capsulatum grows as a multicellular filamentous organism producing characteristic micro- and macro-conidia; at $37^{\circ} \mathrm{C}$ it exists as a unicellular yeast-like organism (Emmons, Binford \& Utz, 1970). The saprobic form of the organism is mycelial and is found in nature, whereas the unicellular yeast-like form is the parasitic phase and is found in tissues during human and animal infection. Both morphologic forms can be cultured in vitro under controlled conditions.

There have been several studies which have compared physiological or chemical characteristics of the two phases but none have attempted to characterize biochemical events during yeast to mycelial $(\mathrm{Y} \rightarrow \mathrm{M})$ or mycelial to yeast $(\mathrm{M} \rightarrow \mathrm{Y}$ ) transitions (Cino \& Tewari, I972; Gupta \& Howard, 197I ; Kobayashi \& Guiliacci, 1967; Mahvi, 1965). As a first step in the characterization of these morphogenetic processes, we have examined RNA metabolism of the yeast, mycelial and intermediate stages during the $M \rightarrow Y$ transition.

\section{METHODS}

Strain and medium. Histoplasma capsulatum (Downs), from the permanent stock culture collection of this laboratory, was maintained in both the yeast and mycelial phases. The yeast cells were grown on $2 \%(w / v)$ glucose, $1 \%(w / v)$ yeast extract agar plates at $37{ }^{\circ} \mathrm{C}$. Before each experiment, 4- to 6-day-old yeast cells were suspended in Salvin's liquid medium (Salvin, 1950) for $48 \mathrm{~h}$. The cells were harvested by centrifugation ( $600 \mathrm{~g}$, $10 \mathrm{~min}$ ) and cell number adjusted with fresh medium to approximately $10^{6}$ cells $/ \mathrm{ml}$. Mycelia were obtained by allowing the yeast cells to germinate and proliferate in Salvin's medium at $25^{\circ} \mathrm{C}$ for 2 to 3 weeks with periodic shaking. The mycelia were transferred to fresh Salvin's medium 3 days before each experiment to provide metabolically active cells.

Measurement of total RNA. Heavy sugar contamination from cell wall material made the conventional orcinol reaction unusable. Instead, RNA was estimated by a modification of the Schmidt-Thannhauser procedure (Fleck \& Munro, 1962). Flasks each containing $50 \mathrm{ml}$ 
of Salvin's medium were inoculated with actively growing yeast cells to a final density of $10^{6}$ to $\mathrm{I} \cdot 5 \times 10^{6}$ cells $/ \mathrm{ml}$ (total dry weight, $\mathrm{I} \cdot 70$ to $2 \cdot 20 \mathrm{mg}$ ) or with $5 \mathrm{ml}$ of concentrated mycelial inocula (average dry weight, $2.0 \mathrm{mg}$ ). The culture flasks were incubated at $37^{\circ} \mathrm{C}$ (yeast and transitional mycelia) or $25^{\circ} \mathrm{C}$ (mycelia) for I, 2, 3 or 4 days with occasional shaking each day; at the end of the growth period each culture was precipitated with $5 \mathrm{ml}$ cold $50 \%$ trichloroacetic acid $\left(\mathrm{CCl}_{3} \mathrm{COOH}\right)$. After they were filtered through glass-fibre discs (2.4 cm, Reeve Angel, New Jersey) and dried, the mycelial or yeast samples were hydrolysed in $2.5 \mathrm{ml} \mathrm{I} \mathrm{N-NaOH}$ at $37^{\circ} \mathrm{C}$ for $\mathrm{I} \mathrm{h}$. The absorbance of the supernatants was read at $260 \mathrm{~nm}$ in a Zeiss spectrophotometer; I unit of absorbance was taken as equal to $40 \mu \mathrm{g} \mathrm{RNA} / \mathrm{ml}$.

Incorporation of nucleic acid precursors. $5-\left[{ }^{3} \mathrm{H}\right]$ uridine (specific activity $8 \mathrm{Ci} / \mathrm{mmol}$ ), $5-\left[{ }^{3} \mathrm{H}\right]$ uracil (specific activity $18 \mathrm{Ci} / \mathrm{mmol}$ ), methyl- $\left[{ }^{3} \mathrm{H}\right]$ thymidine (specific activity ${ }^{6} 6 \cdot 7 \mathrm{Ci} /$ $\mathrm{mmol}$ ), 8-[ $\left.{ }^{3} \mathrm{H}\right]$ guanine (specific activity $\mathrm{I}_{3} \mathrm{Ci} / \mathrm{mmol}$ ) were added to the cultures in Salvin's medium at a concentration of $0.5 \mu \mathrm{Ci} / \mathrm{ml}$ medium; $8-\left[{ }^{14} \mathrm{C}\right]$ guanine (specific activity $50 \mathrm{mCi} /$ mmol) was added at a concentration of $0 . \mathrm{I} \mu \mathrm{Ci} / \mathrm{ml}$ medium. All radioactive compounds were obtained from Schwarz-Mann, Orangeburg, New York, U.S.A. At different times, I $\mathrm{ml}$ samples were precipitated with equal amounts of cold $10 \% \mathrm{CCl}_{3} \mathrm{COOH}$. The precipitates were filtered through glass-fibre discs, washed with cold $5 \% \mathrm{CCl}_{3} \mathrm{COOH}$, then with $\mathrm{O} \cdot \mathrm{I} \mathrm{N}-\mathrm{HCl}$. The discs were dried and counted in toluene scintillation fluid. Under this experimental condition, of those tested, $\left[{ }^{14} \mathrm{C}\right]-$ and $\left[{ }^{3} \mathrm{H}\right]$ guanine were the only radioactive precursors incorporated into the acid precipitable fractions of both the mycelia and yeast.

Isolation and electrophoresis of RNA. RNA from the mycelia and yeast was isolated by a modification of standard methods (Kirby, 1965; Leoning, 1967; Stanley \& Bock, 1965). Yeast or mycelia was grown in Salvin's medium for 2 days, $\left[{ }^{3} \mathrm{H}\right]$ guanine $(0.5 \mu \mathrm{Ci} / \mathrm{ml})$ was then added to mycelia for $4 \mathrm{~h}$ and to yeast for $12 \mathrm{~h}$. The cells were collected by centrifugation at $600 \mathrm{~g}$ for Io min. The sediments were washed twice with extraction buffer ( $2 \%$ sodium acetate, $\mathrm{pH} 5 \cdot 35$, polyvinyl sulphate $20 \mu \mathrm{g} / \mathrm{ml}$ ).

Harvested cells were homogenized with 2 vol. glass beads ( $0.1 \mathrm{I} \mathrm{mm}$ diam) in a cell homogenizer (Braun Model MSK, Bronwill 2876) cooled with liquid $\mathrm{CO}_{2}$. Mycelia were homogenized for $20 \mathrm{~s}$ at $5 \mathrm{~s}$ intervals, while yeast cells were homogenized for $30 \mathrm{~s}$ at $5 \mathrm{~s}$ intervals. The lysates were combined with two washes of glass beads.

Sodium dodecyl sulphate (SDS), I0 $\%(w / v)$, was added to the pooled lysate to a final concentration of $0.1 \%$. RNA was extracted by mixing the lysate vigorously with 2 vol. buffer-saturated phenol for $3 \mathrm{~min}$ at $50{ }^{\circ} \mathrm{C}$. The aqueous phase was recovered by centrifugation at $3000 \mathrm{~g}$ for $\mathrm{I} 5 \mathrm{~min}$, and was re-extracted with I vol. buffer-saturated phenol. The RNA was then recovered from the aqueous phase by precipitation with 2 vol. $95 \%$ cold ethanol $\left(-20^{\circ} \mathrm{C}\right.$ overnight $)$.

The precipitate was centrifuged at $12000 \mathrm{~g}$ for $\mathrm{I} 5 \mathrm{~min}$. The resulting precipitate was dissolved in the electrophoresis buffer (tris, $36 \mathrm{~mm}$; monosodium phosphate, $30 \mathrm{~mm}$; disodium EDTA, I $\mathrm{mM} ; 0.2 \% \mathrm{SDS}, \mathrm{pH} 7 \cdot 6$ ). A sample of the RNA was fractionated in an $8 \mathrm{~cm} \mathrm{r} .8 \%$ acrylamide: $0.5 \%$ agarose gel for $2 \frac{1}{2} \mathrm{~h}$ at $5 \mathrm{~mA} / \mathrm{gel}$. The gel was cut into I. $5 \mathrm{~mm}$ samples, the acrylamide dissolved, and the RNA counted in a liquid scintillation counter.

\section{RESULTS}

\section{Increase in total RNA}

Starting with the same amount of inoculum of yeast and mycelia ( $2 \mathrm{mg}$ dry weight), the increases in total RNA relative to the initial amounts of RNA over a 4 -day period of 


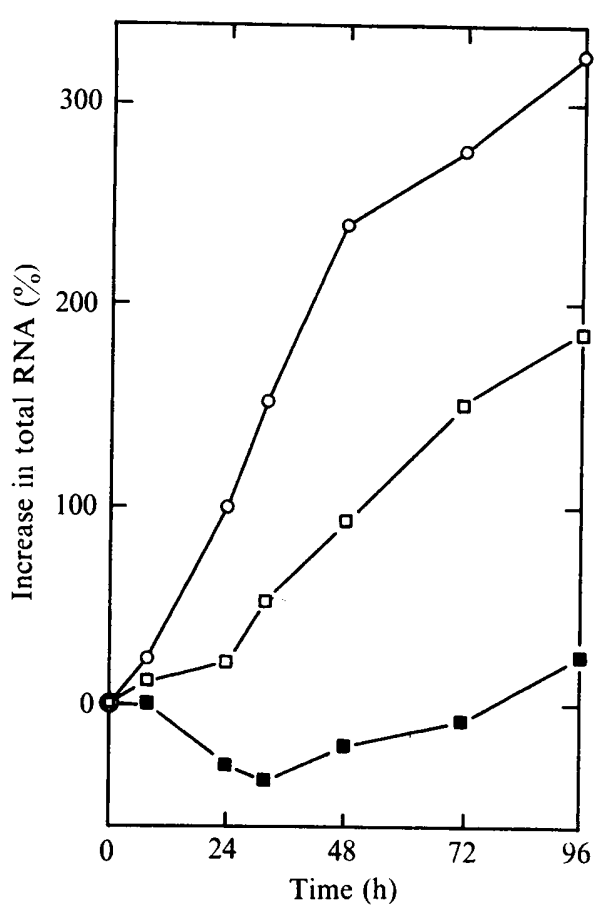

Fig. I

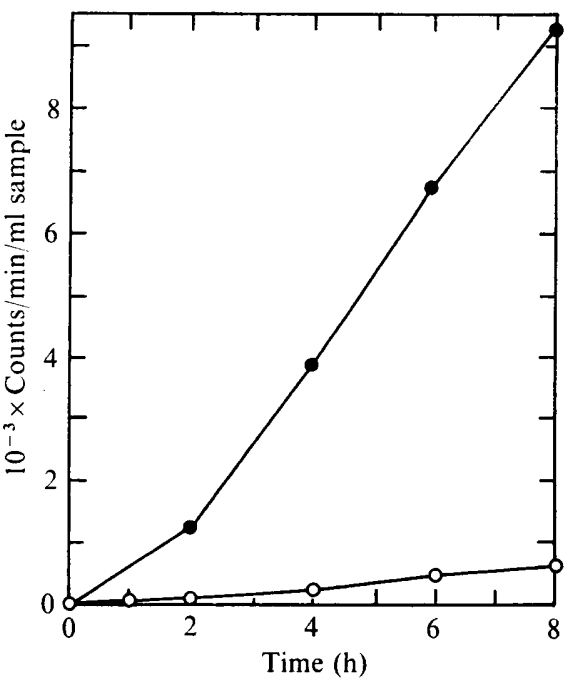

Fig. 2

Fig. I. Increase in total RNA in actively growing yeast cells, mycelia and the $M \rightarrow Y$ transitional phase over a 4-day period of growth. All cultures were started with inocula of $2 \mathrm{mg}$ dry weight. The initial RNA content of mycelia was $102.5 \mu \mathrm{g} ; \mathrm{M} \rightarrow \mathrm{Y}$ transitional phase, $96.5 \mu \mathrm{g}$; and the yeast, $60 \mu \mathrm{g}$. $\mathrm{O}$, Yeast at $37^{\circ} \mathrm{C} ; \square$, mycelia at $25^{\circ} \mathrm{C} ; \boldsymbol{\square}$, mycelia at $37^{\circ} \mathrm{C}$.

Fig. 2. Incorporation of radioactive guanine into the $5 \%$ trichloroacetic acid-precipitable fractions of yeasts $(O)$ and mycelia $(O)$. The results can be converted to c.p.m./ $\mu \mathrm{g}$ RNA by reference to Fig. I; over the $8 \mathrm{~h}$ period of these experiments, the increase in RNA content was about $10 \%$.

growth in the yeast phase, mycelial phase and $\mathrm{M} \rightarrow \mathrm{Y}$ transitional phase (mycelia incubated at $37^{\circ} \mathrm{C}$ ) are shown in Fig. I. There was a $325 \%$ increase in the total RNA in the yeast phase and $\mathrm{I} 85 \%$ in the mycelial phase over the $96 \mathrm{~h}$ of incubation. During the same period of growth the dry weights and total protein contents in the two phases increased at the same rate as the RNA. In the $\mathbf{M} \rightarrow \mathrm{Y}$ transitional phase there was a decrease in the RNA content for the first $32 \mathrm{~h}$; then an increase in RNA was apparent after the next $48 \mathrm{~h}$ of incubation. The development of morphological events in the transitional mycelia closely followed the changes in RNA content because there were no morphological changes in the first $32 \mathrm{~h}$; bud-like hyphal tip constrictions began to emerge after $48 \mathrm{~h}$ when the RNA content increased, and yeast-like cells appeared on these tips by $72 \mathrm{~h}$.

\section{RNA synthesis as measured by guanine incorporation}

New RNA synthesis in $H$. capsulatum was measured by the amount of radioactive guanine incorporated into the cells. By this method, the total RNA synthesized over an $8 \mathrm{~h}$ period was twelve times greater for mycelia than for the yeast cells (Fig. 2).

Fractionation of the RNA on acrylamide gels (Fig. 3) showed that radioactive guanine was incorporated into the large ribosomal RNA molecules $(25 \mathrm{~S}$ and $\mathrm{I} 8 \mathrm{~S})$ of both yeast 

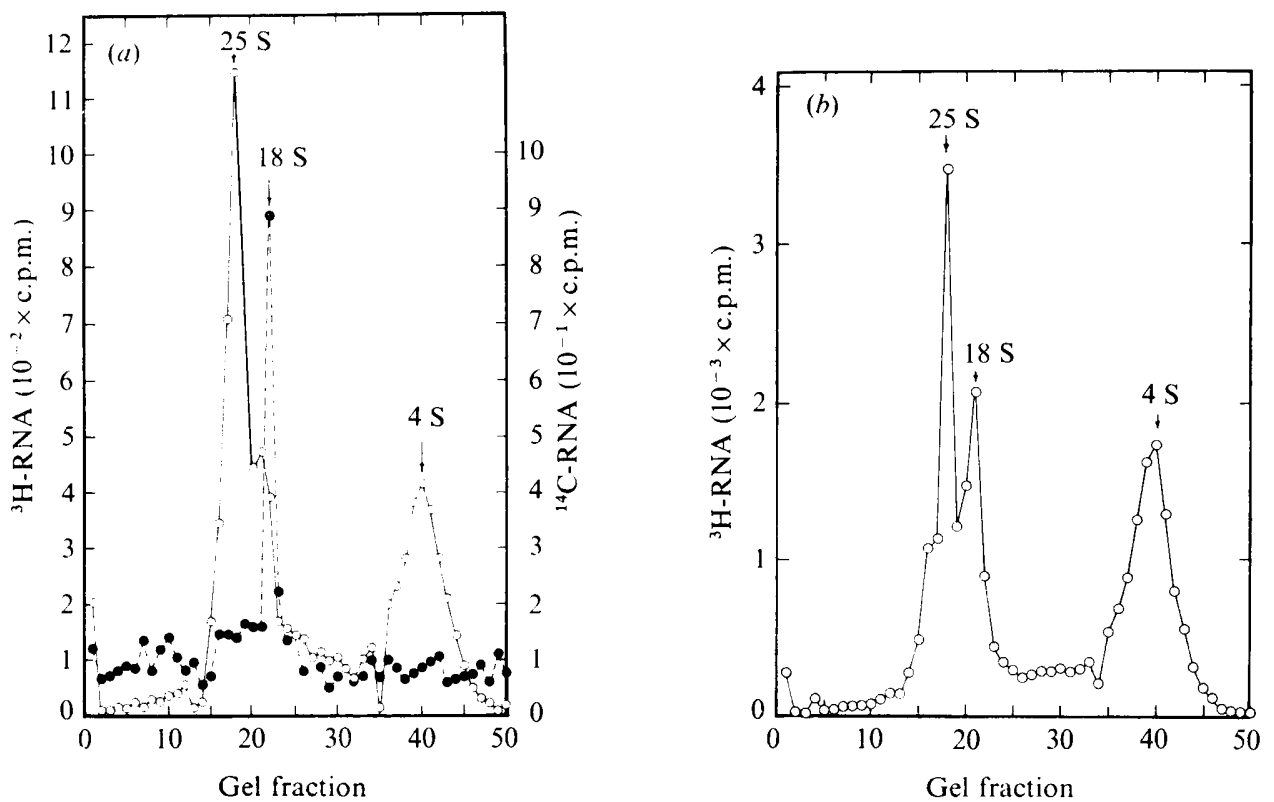

Fig. 3. $\bigcirc$, Polyacrylamide-agarose gel fractionation of RNA isolated from (a) yeast phase and (b) mycelial phase of Histoplasma capsulatum; @, markers from HeLa cells ribosomal RNA.

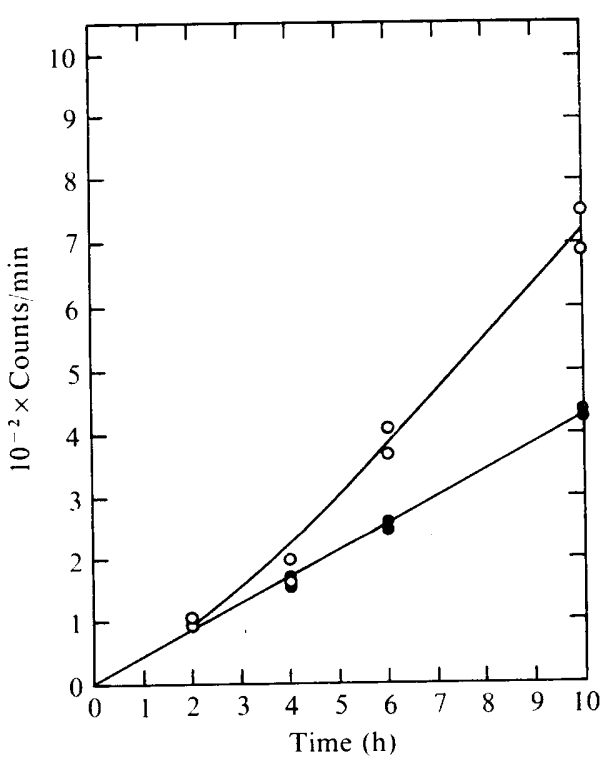

Fig. 4

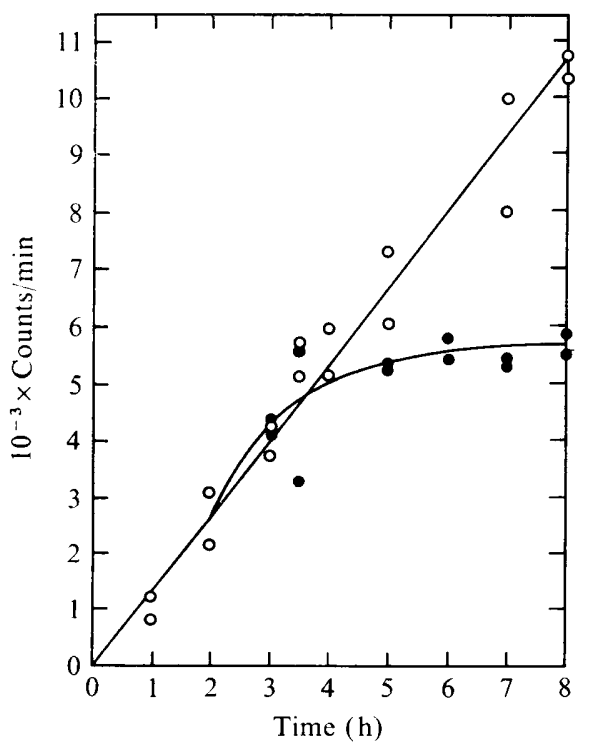

Fig. 5

Fig. 4. Incorporation of radioactive guanine/ml of samples by yeast cells of $\boldsymbol{H}$. capsulatum at $37^{\circ} \mathrm{C}(\bigcirc)$ and $25^{\circ} \mathrm{C}(O)$.

Fig. 5. Incorporation of radioactive guanine/ml samples by mycelia in $\boldsymbol{H}$. capsulatum at $25{ }^{\circ} \mathrm{C}(\mathrm{O})$ and by mycelia at an early stage of transition (O). 


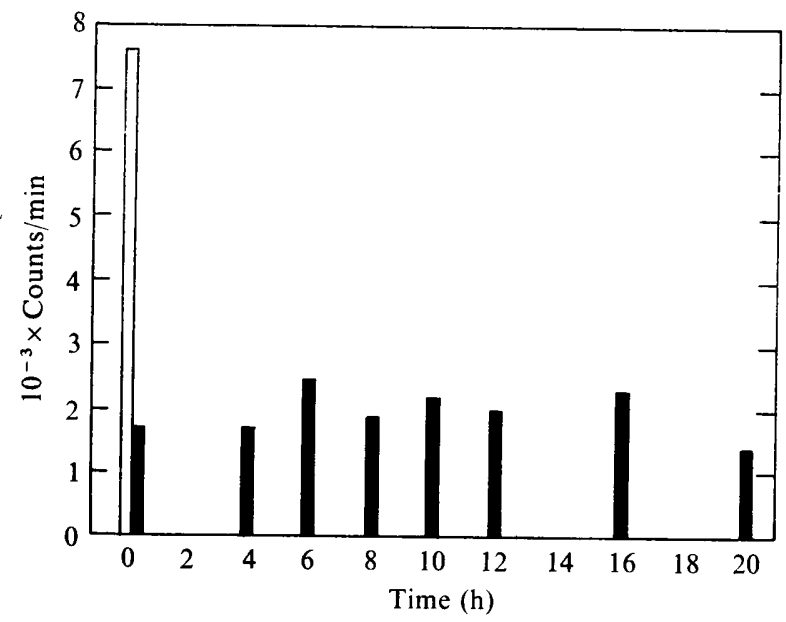

Fig. 6. $\square$, Total amount of radioactive guanine incorporated over a 4-h period by $\mathrm{I}$ ml sample of mycelia at early stages of transition. $\square$, Total amount of guanine incorporated by mycelia at $25{ }^{\circ} \mathrm{C}$ over the same period of time.

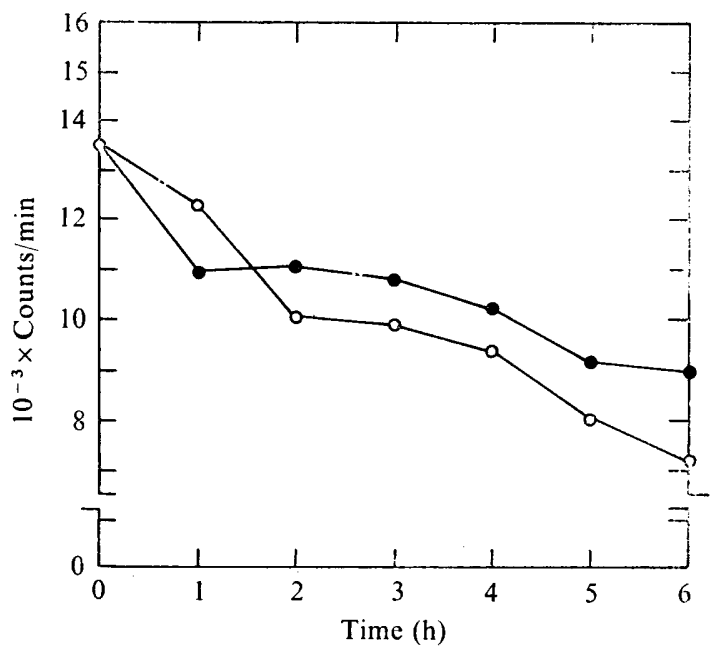

Fig. 7. Degradation of RNA by mycelia at $25^{\circ} \mathrm{C}(\mathrm{O})$ and transitional mycelia at $37^{\circ} \mathrm{C}(\mathrm{O})$ in $H$. capsulatum. Mycelia were pre-incubated with $\left[{ }^{3} \mathrm{H}\right]$ guanine for $4 \mathrm{~h}$, then washed in Salvin's medium. The mycelia were incubated with proflavin $(50 \mu \mathrm{g} / \mathrm{ml})$ for $6 \mathrm{~h} ; \mathrm{I} \mathrm{ml} \mathrm{samples} \mathrm{were} \mathrm{taken}$ over this period. Radioactivity in the mycelia was counted and is expressed per $\mathrm{ml}$ of sample.

and mycelial phases; the gel pattern also showed that yeast and mycelial phases had indistinguishable ribosomal RNA patterns.

Yeast cells transferred from $37^{\circ} \mathrm{C}$ to an incubation temperature suitable for mycelial growth $\left(25^{\circ} \mathrm{C}\right)$ continued to incorporate guanine at a constant but slower rate (Fig. 4). On the other hand, when mycelia growing at $25^{\circ} \mathrm{C}$ were transferred to $37^{\circ} \mathrm{C}$, the optimum temperature for yeast growth, they continued to incorporate guanine for about $2 \mathrm{~h}$, after which time there was an abrupt cessation of apparent net RNA synthesis; this state persisted for at least $4 \mathrm{~h}$ (Fig. 5). During this time, when cells were pulse labelled with $\left[{ }^{3} \mathrm{H}\right]$ guanine, it was obvious that RNA synthesis in the transitional phase proceeded at a slower 
rate than in the mycelial phase (Fig. 6). When these mycelia in transition were incubated with proflavin $(50 \mu \mathrm{g} / \mathrm{ml})$, which inhibited new RNA synthesis in the fungi, RNA degradation occurred at a rate similar to that of mycelia incubated at $25^{\circ} \mathrm{C}$ (Fig. 7).

\section{DISCUSSION}

Growth studies on dimorphic fungi have generally attempted to define the environmental conditions of culture or to determine the specific requirements of certain substances for the initiation of $\mathrm{M} \rightarrow \mathrm{Y}$ or $\mathrm{Y} \rightarrow \mathrm{M}$ conversion (McVeigh \& Houston, 1972; Pine \& Peacock, 1958; Rippon, I968; Scherr, 1957). For example, Rippon (1968) reported the induction of $\mathrm{M} \rightarrow \mathrm{Y}$ conversion in $\boldsymbol{H}$. capsulatum by reducing the oxidation-reduction potential of the culture medium. Scherr (1957) and McVeigh \& Houston (1972) studied the sulphydryl requirement for maintenance of yeast growth after $\mathbf{M} \rightarrow \mathrm{Y}$ conversion. The precise biochemical and physiological changes which occur during the morphological process of $\mathrm{M} \rightarrow \mathrm{Y}$ and $\mathrm{Y} \rightarrow \mathrm{M}$ conversion in $H$. capsulatum is still little understood.

We have studied RNA metabolism in actively growing yeast phase, mycelial phase and $\mathrm{M} \rightarrow \mathrm{Y}$ transitional forms of $H$. capsulatum. RNA synthesis in these cells can be measured by the direct determination of RNA, or by incorporation of radioactive substrates. In $H$. capsulatum, both of these methods have inherent problems. First, the heavy sugar contamination from cell wall material disqualified the use of the orcinol reaction. Second, radioisotope experiments have been very difficult to perform with $H$. capsulatum because few precursors tested were incorporated; other workers have encountered similar difficulty (R. Tewari, personal communication). Even for guanine utilization, the specific activity of RNA formed by actively growing yeast was much lower than that formed in mycelia (Fig. 2), so that the uptake of this metabolite differs for the two growing states. Thus, the increase of labelled RNA in both the yeast and mycelial phase (Fig. 2) was consistent with the absolute increase in RNA (Fig. I), but the low labelling rate in the yeast phase meant that the absolute determination was a better measure of net RNA increase. In the $M \rightarrow Y$ transition phase, the low labelling rate was in agreement with the absolute determination. Therefore, during the initial stages of the $M \rightarrow Y$ transition, RNA synthesis decreased to a low level but RNA catabolism continued at a constant level. This resulted in a cessation of net RNA synthesis (Fig. 5).

Acrylamide gel electrophoresis of the RNA of the yeast and mycelial phase did not reveal any differences, but this does not rule out differences in the RNA or modification of ribosomal RNA which do not affect migration in the gels. The morphological changes during the $\mathrm{M} \rightarrow \mathrm{Y}$ transition seem to be correlated with changes in RNA metabolism. When mycelia were placed at $37^{\circ} \mathrm{C}$, a sufficient trigger for the transition, net RNA synthesis stopped. After the lag, there was a resumption of RNA synthesis and this was paralleled by the emergence of yeast-like structures in the transforming cells. The mechanism of the sudden decrease in RNA synthesis during the $\mathrm{M} \rightarrow \mathrm{Y}$ conversion at $37^{\circ} \mathrm{C}$ is unknown but one hypothesis we are currently studying is whether it is based on a temperature-dependent change of the RNA polymerases.

This investigation was supported in part by National Institutes of Health Grants Nos. AI 06213, AI 10622 and AM 056II, and grants from the John A. Hartford Foundation, Inc. and the Research Corporation (Brown-Hazen Fund). 


\section{REFERENCES}

Cino, P. M. \& Tewari, R. P. (1972). Chemical composition of Histoplasma capsulatum. Mycopathologia et mycologia applicata 47, 285-294.

Emmons, C. W., Binford, C. B. \& Utz, J. P. (1970). Medical Mycology, 2nd edn, p. 30i. Philadelphia: P. Lea \& Febiger.

Fleck, A. \& Munro, H. N. (I962). The precision of ultraviolet absorption measurements in the SchmidtThannhauser procedure for nucleic acid estimation. Biochimica et biophysica acta 55, 571-583.

GuPTA, R. K. \& HowARD, D. H. (197I). Comparative physiological studies of the yeast and mycelial forms of Histoplasma capsulatum: uptake and incorporation of L-leucine. Journal of Bacteriology 105, 690-700.

KIRBY, K. S. (1965). Isolation and characterization of ribosomal ribonucleic acid. Biochemical Journal 96, 266-269.

Kobayashi, G. S. \& Gulliacci, P. L. (1967). Cell wall studies of Histoplasma capsulatum. Sabouraudia 5, I80-I88.

LEONING, U. E. (I967). The fractionation of high molecular weight ribonucleic acid by polyacrylamide gel electrophoresis. Biochemical Journal 102, 25 I-257.

Marvi, T. A. (1965). A comparative study of the yeast and mycelial phases of Histoplasma capsulatum. I. Pathways of carbohydrate dissimilation. Journal of Infectious Diseases 115, 226-232.

MCVeIGh, I. \& HouSton, W. H. (1972). Factors affecting mycelial to yeast phase conversion and growth of the yeast phase of Histoplasma capsulatum. Mycopathologia et mycologia applicata 47, $135-151$.

Pine, L. \& PeACOCK, C. L. (1958). Studies on the growth of Histoplasma capsulatum. IV. Factors influencing conversion of the mycelial phase to yeast phase. Journal of Bacteriology 75, 167-1 74.

RIPPON, J. W. (1968). Monitored environment system to control cell growth. Morphology, and metabolic rate in fungi by oxidation reduction potentials. Applied Microbiology 16, I I4-I 2 I.

Salvin, S. B. (1950). Growth of the yeastlike phase of Histoplasma capsulatum in a fluid medium. Journal of Bacteriology 59, 312.

SCHERR, G. H. (1957). Studies on the dimorphism of Histoplasma capsulatum. I. The role of -SH groups and incubation temperature. Experimental Cell Research 12, 92-107.

Stanley, W. M., Jun. \& Bock, R. M. (1965). Isolation and physical properties of the ribosomal ribonucleic acid of E. coli. Biochemistry 4, 1302-131 I. 